University of Nebraska - Lincoln

DigitalCommons@University of Nebraska - Lincoln

2-8-2020

\title{
Dental microwear as a behavioral proxy for distinguishing between canids at the Upper Paleolithic (Gravettian) site of Predmostí, Czech Republic
}

\author{
Kari A. Prassack \\ Josephine DuBois \\ Martina Laznickova-Galetova \\ Mietje Germonpre
}

Peter S. Ungar

Follow this and additional works at: https://digitalcommons.unl.edu/natlpark

Part of the Environmental Education Commons, Environmental Policy Commons, Environmental Studies Commons, Fire Science and Firefighting Commons, Leisure Studies Commons, Natural Resource Economics Commons, Natural Resources Management and Policy Commons, Nature and Society Relations Commons, Other Environmental Sciences Commons, Physical and Environmental Geography Commons, Public Administration Commons, and the Recreation, Parks and Tourism Administration Commons

This Article is brought to you for free and open access by the National Park Service at DigitalCommons@University of Nebraska - Lincoln. It has been accepted for inclusion in U.S. National Park Service Publications and Papers by an authorized administrator of DigitalCommons@University of Nebraska - Lincoln. 


\title{
Dental microwear as a behavioral proxy for distinguishing between canids at the Upper Paleolithic (Gravettian) site of Predmostí, Czech Republic
}

\author{
Kari A. Prassack ${ }^{\mathrm{a}, *}$, Josephine DuBois ${ }^{\mathrm{b}, \mathrm{c}}$, Martina Laznickova-Galetova ${ }^{\mathrm{d}}$, Mietje Germonpre ${ }^{\mathrm{e}}$, \\ Peter S. Ungar ${ }^{c}$ \\ ${ }^{a}$ Hagerman Fossil Beds National Monument, National Park Service, 221 N. State Street, Hagerman, ID, 83332, USA \\ ${ }^{\mathrm{b}}$ University of Missouri Kansas City School of Dentistry, 650 E 25th St, Kansas City, MO, 64108, USA \\ ${ }^{\mathrm{c}}$ Department of Anthropology, University of Arkansas 330 Old Main, Fayetteville, AR, 72701, USA \\ ${ }^{\mathrm{d}}$ Moravian Museum, Zelný trh 6, 659 37, Brno, Czech Republic \\ e Operational Direction "Earth and History of Life", Royal Belgian Institute of Natural Sciences, Vautierstraat 29, 1000, Brussels, Belgium
}

\section{A R T I C L E I N F O}

\section{Keywords:}

Canis familiaris

Canis lupus

Dog domestication

Dietary behavior

Dental microwear texture analysis

Upper paleolithic/palaeolithic

\begin{abstract}
A B S T R A C T
Morphological and genetic evidence put dog domestication during the Paleolithic, sometime between 40,000 and 15,000 years ago, with identification of the earliest dogs debated. We predict that these earliest dogs (referred to herein as protodogs), while potentially difficult to distinguish morphologically from wolves, experienced behavioral shifts, including changes in diet. Specifically, protodogs may have consumed more bone and other less desirable scraps within human settlement areas. Here we apply Dental Microwear Texture Analysis (DMTA) to canids from the Gravettian site of Predmostí (approx. 28,500 BP), which were previously assigned to the Paleolithic dog or Pleistocene wolf morphotypes. We test whether these groups separate out significantly by dietrelated variation in microwear patterning. Results are consistent with differences in dietary breadth, with the Paleolithic dog morphotype showing evidence of greater durophagy than those assigned to the wolf morphotype. This supports the presence of two morphologically and behaviorally distinct canid types at this middle Upper Paleolithic site. Our primary goal here was to test whether these two morphotypes expressed notable differences in dietary behavior. However, in the context of a major Gravettian settlement, this may also support evidence of early stage dog domestication. Dental microwear is a behavioral signal that may appear generations before morphological changes are established in a population. It shows promise for distinguishing protodogs from wolves in the Pleistocene and domesticated dogs from wolves elsewhere in the archaeological record.
\end{abstract}

\section{Introduction}

\subsection{Dog domestication}

Dog domestication is the earliest example of animal husbandry and the only domestication type thought to occur prior to the advent of agriculture (Clutton-Brock, 1995, 2016). It likely began as a series of mutualistic, proto-domestication processes; slow, non-deliberate shifts in the human-canid relationship over millennia (Coppinger and Coppinger, 2001; Galibert et al., 2011; Zeder, 2012; Thalmann et al., 2013; Morey and Jeger, 2015; Germonpre et al., 2018). Morphological and genetic data confirm that dogs (Canis familiaris) are descendants of Eurasian grey wolves (Canis lupus) (Wayne, 1986; Tchernov and Horwitz, 1991; Clutton-Brock, 1995; Vila et al., 1997; Coppinger and
Coppinger, 2001; Morey and Jeger, 2015). Early human-wolf associations, indicative of shared resources and territories, date back several hundred thousand years (Galibert et al., 2011; Clutton-Brock, 2016). Osteological changes strongly suggestive of dog domestication do not appear, however, until the Aurignacian (Table 1). By 16,000-12,000 BP, domestic dogs were established and present at sites from Western Europe across Asia and into North America (Morey, 2010, 2014; Boudadi-Maligne et al., 2012; Larson et al., 2012; Thalmann and Perri, 2018). Purposeful burials are also evident by this time (Janssens et al., 2018). The beginning of this domestication process, however, remains a point of debate, with purported originations ranging from 15,000 to over 40,000 BP (Savolainen et al., 2002; Germonpre et al., 2009; Thalmann et al., 2013; Morey, 2014). Notably, the older end of this range is roughly coincident with the migration of Homo sapiens into Europe

\footnotetext{
* Corresponding author.

E-mail address: kari_prassack@nps.gov (K.A. Prassack).
} 
Table 1

Canid fossils identified as dogs in the Pleistocene-early Holocene (Greelandian) zooarchaeological record. Calibrated dates are prefixed with cal.

\begin{tabular}{|c|c|c|c|}
\hline Locality & Age (BP) & Period & Primary source \\
\hline Goyet Cave, Belgium & cal. 35,700 & Aurignacian & Germonpre et al. (2009) \\
\hline Razboinichya, Siberia & cal. 33,000 & NA & Ovodov et al. (2011); Druzhkova et al. (2013) \\
\hline Hohle Fels, Germany & $29,800-35,700$ & Gravettian & Conard and Bolus (2008); Camaros et al. (2016) \\
\hline Predmostí, Czech Republic & cal. 28,500 & Gravettian & Germonpre et al. (2017a) \\
\hline Ulakhan Sular, Siberia & cal. 16,900 & NA & Germonpre et al. (2017b) \\
\hline Eliseevichi, Russia & cal. 16,500 & Epigravettian & Sablin and Khlopachev, (2002) \\
\hline Mezin, Ukraine & $20,000-8000$ & Epigravettian & Benecke (1987); Pidoplichko (1998); Germonpre et al. (2009) \\
\hline Mezhirich, Ukraine & 14,500 & Epigravettian & Germonpre et al. (2009) \\
\hline Abri du Morin, France & cal. 14,700 & Magdalenian & Boudadi-Maligne et al. (2012) \\
\hline Bonn-Oberkassel, Germany & cal. 14,100 & Magdalenian & Nobis, 1979; Street et al. (2015); Janssens et al. (2018) \\
\hline Kesslerloch Cave, Switzerland & cal. 14,100 & Magdalenian & Napierala and Uerpmann, (2012) \\
\hline Ein Mallaha, Palestine & 12,000 & Natufian & Davis and Valla, (1978) \\
\hline Saint-Thibauld, France & cal. 11,600 & Epipaleolithic & Chaix, (2000) \\
\hline Senckenburg, Germany & $12,000-9000$ & Mesolithic & Degerbal (1961) \\
\hline Danger Cave, Utah, USA & 11,000 & Early Archaic & Grayson et al. (1988) \\
\hline Koster Site, Illinois, USA & cal. 9900 & Early Archaic & Perri et al. (2019) \\
\hline Stilwell II Site, Illinois, USA & cal. 9900 & Early Archaic & Perri et al. (2019) \\
\hline
\end{tabular}

(Conard and Bolus, 2008). Animal domestication involves shaping and controlling the evolutionary pathway of another species; thereby reflecting a shift in the human psyche on its relationship with nature (Boudadi-Maligne et al., 2012; Jung and Portl, 2018). The timing of this first domestication process is important knowledge for understanding early Homo sapiens cognition, behavior, and ecology during the Last Glacial Period as well as for discerning the initial impetus for human-wolf interactions.

\subsection{Morphological studies on dog domestication}

Morphological and morphometric evidence of dog domestication includes tooth crowding, carnassial size reduction, snout length reduction and breadth expansion, sagittal crest reduction, differences in mandibular shape, orientation, and robusticity, paedomorphosis, and higher incidence of dentognathic pathologies (Germonpre et al., 2009, 2012; Ovodov et al., 2011, 2015b, 2017b). That said, the utility of such traits for distinguishing dogs from wolves has been strongly contested (Crockford and Kuzmin, 2012; Boudadi-Maligne and Escarguel, 2014; Morey, 2014; Drake et al., 2015; Janssens et al., 2016, 2019; Perri, 2016; Ameen et al., 2017). Some studies, for example, argue the Paleolithic protodog morphotype may reflect variability within and across wolf populations (Larson et al., 2012; Drake et al., 2015; Perri, 2016; Janssens et al., 2019).

Wolf morphological variation during the Pleistocene, while evident (Boudadi-Maligne and Escarguel, 2014; Meachen et al., 2016), remains poorly understood (Drake et al., 2015; Skoglund et al., 2015; Perri, 2016). Climate-induced environmental shifts, including changes in prey type, may have led to body size differences among late Pleistocene canids, producing distinct size gradients among sympatric or seasonally overlapping wolf populations (Leonard et al., 2007; O'Keefe et al., 2013; Sansalone et al., 2015; Flower, 2016). Modern and historic dog and wolf populations exhibit great breadth in body size (Losey et al., 2015) and morphology (Nowak and Federoff, 2002), and even recent historical dog populations are sometimes difficult to distinguish from wolves (Fisher, 2019).

These ambiguities can limit the utility of morphological variation among Pleistocene canids as evidence of domestication (Morey, 2010; Crockford and Kuzmin, 2012; Boudadi-Maligne and Escarguel, 2014). Further, domestication morphotypes can lag thousands of years behind the initial beginnings of the domestication process (Zeder and Hesse, 2000; Rossel et al., 2008; Outram et al., 2009; Larson et al., 2012) and related behavioral changes (Pendleton et al., 2018), making origination dates difficult to discern in the zooarchaeological record. We refer to these earliest purported dogs as protodogs, and recognize that they may represent either failed or successful examples of early wolf domestication (sensu Coppinger and Coppinger, 2001; Galibert et al., 2011).

\subsection{Genetic studies on dog domestication}

Vila et al. (1997) placed dog genetic origins at 135,000 BP, but more recent studies suggest that initial wolf-dog population divergence occurred between 27,000 and 41,500 BP (Skoglund et al., 2015; Botigue et al., 2017). The Middle East (Gray et al., 2010; vonHoldt et al., 2012), East Asia (Leonard et al., 2002; Savolainen et al., 2002; Pang et al., 2009; Wang et al., 2016) and Central Asia (Shannon et al., 2015) have each been suggested as potential epicenters for dog origin(s). Fossil records in those regions, however, are limited to the post-Last Glacial Maximum, around 13,000 years ago (Larson et al., 2012). Central Europe maintains the strongest uncontested early fossil record of dog domestication (Thalmann et al., 2013) and the presence of earlier, albeit contested, protodogs supports the genetic evidence for a middle or late Upper Paleolithic timeline (Thalmann et al., 2013; Skoglund et al., 2015; Botigue et al., 2017; Ciucani et al., 2019).

Genetic admixture, bottleneck events (Leonard et al., 2007; Pilot et al., 2014; Ersmark et al., 2016; Ciucani et al., 2019), and the geographic isolation of dog populations and subsequent phenotypic changes in dog breeds, through isolation and intensive breeding, complicates interpretations of genetic signals (Larson et al., 2012; Thalmann et al., 2013; Shannon et al., 2015). There are difficulties in distinguishing extant wolf species due to crossbreeding (Wilson et al., 2000) and ecotypic variability that can produce morphological, genetic, and isotopic differences (Pilot et al., 2012; Schweizer et al., 2015). Dog domestication may have occurred as a series of spatially disparate domestication (including failed) events (vonHoldt et al., 2012; Thalmann et al., 2013; Germonpre et al., 2015a; Skoglund et al., 2015; Frantz et al., 2016); a complicated admixture of newly forming dog and sympatric wolf populations (vonHoldt et al., 2012; Morey, 2014, but see Botigue et al., 2017). Dogs could even derive from a now-extinct lineage of wolves (Freedman et al., 2014; Larson and Bradley, 2014; Perri, 2016; vonHoldt and Driscoll, 2016).

These factors may limit the utility of genetic profiles as evidence of dog antiquity (Larson et al., 2012; Freedman et al., 2014; Marsden et al., 2016, but see the use of village dogs by Pendleton et al., 2018).

\subsection{Potential behavioral differences related to diet}

The first canids to enter human settlements (either purposely or brought in by humans) can be expected to have altered their diets compared to wild conspecifics. Such behavioral shifts could have occurred generations prior to the establishment of diagnostic 
morphological or genetic changes. The scavenging hypothesis of Coppinger and Coppinger (2001) suggests dog self-domestication occurred via scavenging, though they predicted a later, post-agricultural domestication. Human refuse exploitation is a learned behavior seen in free ranging dogs (Vanak and Gompper, 2009; Forsyth et al., 2014), and other canids, including coyotes, foxes and wolves today (Murray et al., 2015; Bateman and Fleming, 2012; Forsyth et al., 2014). It is unclear whether Paleolithic campsites contained enough surplus or refuse to entice invasive wolves (Lupo, 2017; Germonpre et al., 2018; Jung and Portl, 2018), but scavenging efficiency of protodogs may have been encouraged as a means of site management by removing refuse from occupation sites (Coppinger and Coppinger, 2001; Russell and Twiss, 2017).

\subsection{Evidence of bone consumption by dogs}

Domestication would have decreased inherent fear of humans in protodogs and facilitated consumption of human-accumulated prey carcasses by dogs compared to wild carnivorans (Butler and Du Toit, 2002). Scavenging, unless early access (e.g., kleptoparasitic), should lead to increased bone breakage and consumption to access remaining nutrients. Losey et al. (2014) reported a higher incidence of tooth fracture among historic dogs compared to wolves as evidence of such scavenging behaviors, and even a proclivity for bone consumption by dogs when otherwise fed at human settlements. Modern studies of wolves supports this (Van Valkenburgh et al., 2019) but others, using microwear analysis, have questioned the correlation between tooth breakage and bone consumption (DeSantis et al., 2012, 2015). In archaeological context, dogs may shape faunal assemblages through bone destruction and consumption of refuse (Munson, 2000; Atici, 2006; Russell and Twiss, 2017, but see Horwitz, 1990). Tooth-marked bone can be used as evidence of bone consumption, but identifying the mammalian predator responsible, based on tooth mark size and shape, has been met with mixed results (Selvaggio and Wilder, 2001; Domínguez-Rodrigo and Piqueras, 2003; Coard, 2007; Delaney-Rivera et al., 2009; Andres et al., 2012; Parkinson et al., 2015). It would be particularly difficult to distinguish tooth marks made by two canids of similar size.

Dental and cranial morphology provide insights into dietary behavior, but these can be phylogenetically constrained, making diet interpretations difficult (Popowics, 2003; Sacco and Van Valkenburgh, 2004; Goillot et al., 2009). That said, the shorter, more robust mandibular rami of protodogs (Germonpre et al., 2015a) are consistent with selection to generate, transmit, and dissipate the forces necessary to break bone (Wroe et al., 2005). Modern free ranging and feral dogs do scavenge and consume bone (Lyon, 1970; Butler and Du Toit, 2002; Forsyth et al., 2014), and a shift towards increased scavenging in association with human settlements is plausible. This would have left distinct dietary traces on the dentition of protodogs. Dental microwear provides a means of testing this, without the potential ambiguities of taphonomic analysis.

\subsection{Revealing animal dietary behaviors using dental microwear texture analysis (DMTA)}

Dental microwear is dietary trace evidence left during the days to weeks prior to an individual's death (Grine, 1986). Dental Microwear Texture Analysis (DMTA) applies scale sensitive fractal geometry to specimens measured under confocal light microscopy (Ungar et al., 2003; Scott et al., 2005, 2006). Unlike older dental wear methods (e.g., Van Valkenburgh et al., 1990; King et al., 1999; Merceron et al., 2005; Goillot et al., 2009), DMTA provides automated measures less susceptible to observer measurement error, hence potentially increasing the signal-to-noise ratio. This behavioral proxy presents refined scale differences across specimens or taxa not discernible at coarser scales (Ungar, 2009).
DMTA facilitates the reconstruction of dietary behaviors of extinct taxa (e.g., Scott et al., 2005; Schubert et al., 2010; Stynder et al., 2012; DeSantis et al., 2013; Donohue et al., 2013; DeSantis et al., 2015; Caporale and Ungar, 2016; Ungar et al., 2017; Stynder et al., 2018; Tanis et al., 2018). It can provide insight on cryptic, or otherwise poorly understood species (Purnell et al., 2013) and both differentiate intraspecific differences across contemporaneous populations (Kubo et al., 2017) and reveal shifts (e.g., changes in diet, competition) between current and historic ones (DeSantis, 2016), even across deeper geologic time (Schubert et al., 2010; DeSantis and Haupt, 2014). Among carnivorans, microwear is especially useful for distinguishing flesh specialists (i.e., soft and tough foods) from those that consume hard or brittle foods, such as bone (Schubert et al., 2010; Bastl et al., 2012; Stynder et al., 2012). Microwear analysis has even helped document the dynamics of carcass acquisition and competition within carnivoran paleoguilds (DeSantis et al., 2012, 2015) and, in doing so, tested earlier hypotheses (Van Valkenburgh and Hertel, 1993) about the correlation between tooth breakage and bone consumption. Importantly, microwear can identify behavioral changes (i.e., diet) that may occur prior to notable morphological changes associated with that type of diet (Tseng, 2012).

Here, we compare microwear textures of canids from Predmostí, Czech Republic, one of the earliest recognized potential protodog sites (Germonpre et al., 2012). The idea is to test the hypothesis that those individuals identified as protodogs (with shorter, deeper mandibles better suited to crushing bone) indeed crushed bone more regularly than the wolves. This would be consistent with the notion that canids beginning to co-habitat within or along the edges of human encampments consumed less desirable food items, including bone, discarded or fed to them by humans.

\subsection{Canids of Predmosti, Czech Republic}

Predmostí is a Gravettian open-air site in the Moravian Corridor, Czech Republic (Fig. 1). It is known for its large skeletal accumulations of humans (Velemínska and Brůzek, 2008), mammoths (Musil, 2008), and canids (Pokorný, 1951), including human-modified canid bone and teeth (Germonpre et al., 2012, 2017a). Pokorný (1951) recognized two distinct canid morphotypes: Canis lupus major and Canis lupus minor, which Musil (2000) later attributed to sexual dimorphism. Benecke (1994) separated these morphotypes into wolves and domesticated canids, using tooth crowding as evidence of domestication. Tooth crowding alone is not a good indicator of domestication (Ameen et al., 2017), but Germonpre et al. (2012) provided additional cranial morphologies to support the presence of domestic dogs. Germonpre et al. (2015a) further differentiated between the robust, short jawed "Paleolithic dog" (n 37) and slender elongated "Pleistocene wolf" morphotypes (n 37) using a series of morphotypic differences in the mandible (Fig. 2). Their assertion and use of these traits has been contested (e.g., Crockford and Kuzmin, 2012; Boudadi-Maligne and Escarguel, 2014; Morey, 2014; Perri, 2016). Here, we predict that these morphological differences reflect differences in diet, with the robust and shorter jawed canids likely to have consumed more bone. Microwear analysis provides an independent means of predicting whether a specimen at Predmostí, identified as wolf or protodog elsewhere, differed in diet as expected given variation in mandibular dimensions.

\section{Materials and methods}

\subsection{Specimens used}

Specimens used in this study (n 20, Supplementary Material A) are housed in the off-site depository of the Moravian Museum, Brno, Czech Republic. Germonpre et al. (2015a) previously assigned these canids as either Paleolithic dog or Pleistocene wolf based on mandibular and dental measures (Fig. 2). We use previously established categories (protodog and wolf) rather than Group A and Group B to recognize 


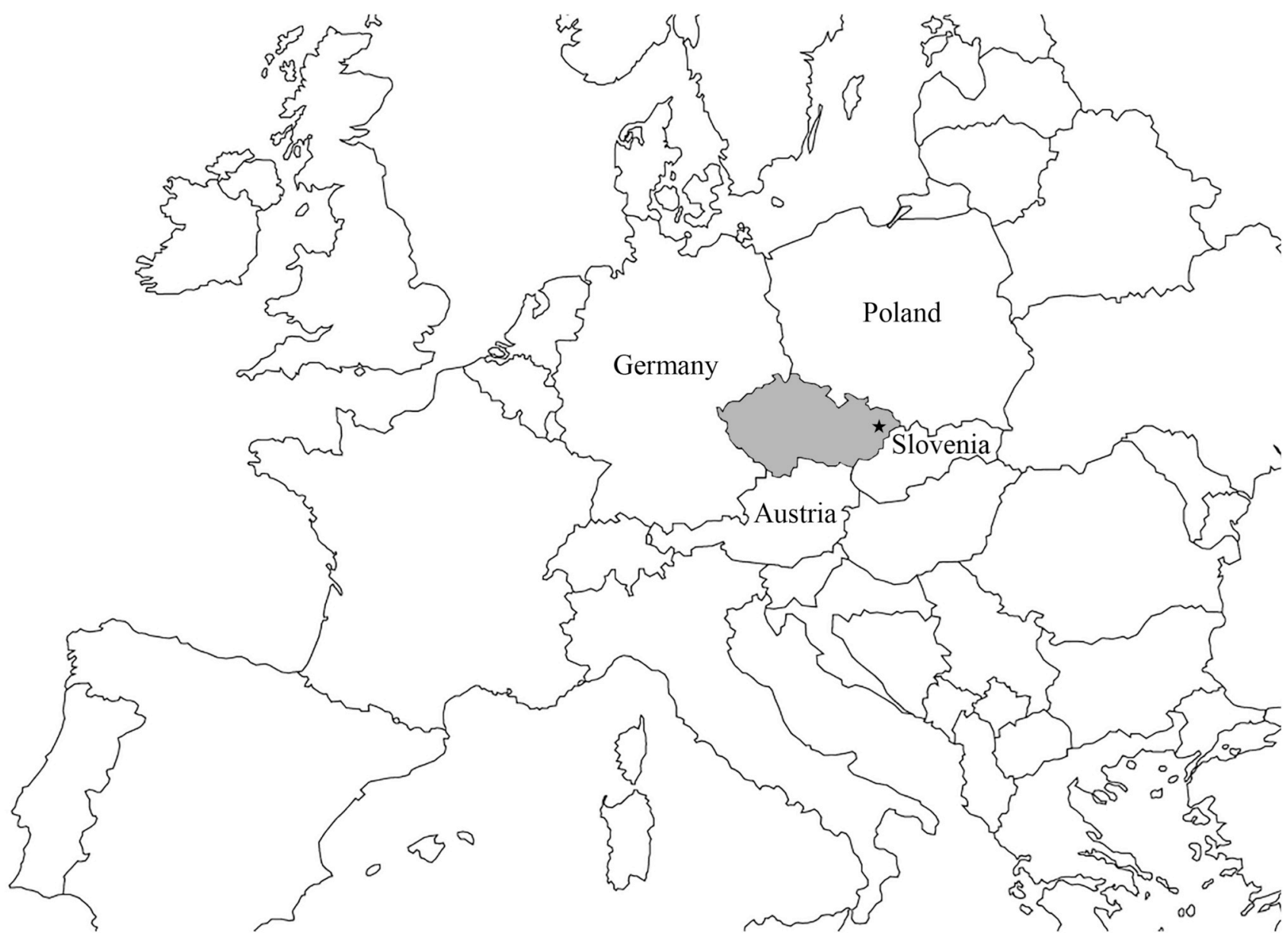

Fig. 1. Map of Europe showing the location of Predmostí (star), a Gravettian open-air site in the Moravian Corridor, Czech Republic (country greyed).
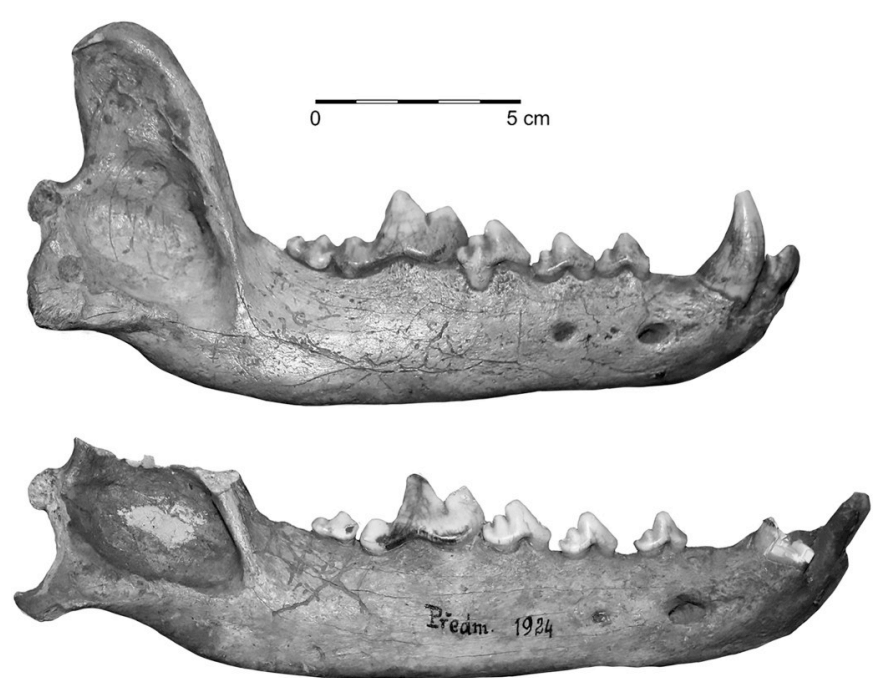

Fig. 2. Comparison of dog-like (top, specimen \#25) and wolf-like (bottom, specimen \#55) morphotypes (Supplementary Material A), assigned by Germonpre et al. (2012, 2015a) as either Paleolithic dog or Pleistocene wolf, from Predmostí, a Gravettian open-air site in the Moravian Corridor, Czech Republic. Measurements: \#25 total mandibular length, $171.0 \mathrm{~mm}$; carnassial length, $29.5 \mathrm{~mm}$ \#55 total mandibular length, $193.0 \mathrm{~mm}$; carnassial length, $28.3 \mathrm{~mm}$. previous studies and the relevancy of those descriptors to the formulation of our hypothesis. We are only testing the validity of separating these two canid morphotypes, and our categorization does not preclude the potential that both groups represent morphologically and behaviorally distinct wild canids.

\subsection{Phylogenetic considerations}

Feliforms (felids and hyaenids) lack post-carnassial dentition (i.e., $\mathrm{M}_{2}-\mathrm{M}_{3}$ in the lower dental arcade) and primarily use their lower carnassial $\left(\mathrm{M}_{1}\right)$, with hyeanids also utilizing their highly adapted premolars, for crushing (Van Valkenburgh et al., 1990; Van Valkenburgh, 1996; Stynder et al., 2012). Canids retain those post-carnassial molars, and the $\mathrm{M}_{1}$ and $\mathrm{M}_{2}$ tend to record shearing actions related to meat consumption and bone crushing, respectively (Van Valkenburgh, 1989, 1996; Biknevicus et al., 1996; Ungar et al., 2010). This makes the $\mathrm{M}_{2}$ a more suitable proxy for distinguishing canid diets as they relate to crushing hard or brittle food items (Ungar et al., 2010; Tanis et al., 2018). We therefore anticipated differences on the $M_{2}$ but not the $M_{1}$ of Predmostí canids with the protodog morphotype showing a proclivity for bone cracking.

\subsection{Data collection and analysis}

We selected specimens from each canid morphotype based on molariform tooth condition (lack of postmortem damage or adherents) with emphasis on the trigonid shearing facet of the $\mathrm{M}_{1}$ and the antereolingual surface of the $\mathrm{M}_{2}$ hypoconid. This region of the $\mathrm{M}_{2}$ is analogous to Facet 9, the "Phase II" or post-centric occlusion of primate based 
Table 2

Summary statistics for Scale Sensitive Fractal Analysis (SSFA) of the $M_{1}$ and $M_{2}$ from Predmostí canids identified as either Paleolithic dog or Pleistocene wolf by Germonpre et al. (2015a). See Supplementary Material A for raw data.

\begin{tabular}{|c|c|c|c|c|c|}
\hline & & Asfc & Smfc & HAsfc9 & HAsfc81 \\
\hline \multicolumn{6}{|c|}{ Paleolithic dog } \\
\hline \multirow{3}{*}{$\mathrm{M}_{1 \text { (n }}$ 9) } & mean & 1.727 & 1.58 & 0.254 & 0.464 \\
\hline & median & 1.44 & 1.21 & 0.209 & 0.448 \\
\hline & standard deviation & 0.964 & 1.083 & 0.107 & 0.145 \\
\hline \multirow{3}{*}{$\mathrm{M}_{2 \text { (n } 10)}$} & mean & 1.16 & 2.64 & 0.312 & 0.472 \\
\hline & median & 1.085 & 1.86 & 0.23 & 0.407 \\
\hline & standard deviation & 0.54 & 1.042 & 0.221 & 0.185 \\
\hline \multicolumn{6}{|c|}{ Pleistocene wolf } \\
\hline \multirow[t]{3}{*}{$\left.\mathrm{M}_{1(\mathrm{n}} \quad 10\right)$} & mean & 1.89 & 1.21 & 0.297 & 0.498 \\
\hline & median & 1.965 & 1.445 & 0.29 & 0.517 \\
\hline & standard deviation & 0.788 & 1.296 & 0.1 & 0.196 \\
\hline \multirow[t]{3}{*}{$\left.\mathrm{M}_{2(\mathrm{n}} \quad 10\right)$} & mean & 1.156 & 1.109 & 0.356 & 0.595 \\
\hline & median & 1.18 & 1.21 & 0.22 & 0.415 \\
\hline & standard deviation & 0.408 & 0.299 & 0.335 & 0.332 \\
\hline
\end{tabular}

microwear studies (Krueger et al., 2008). Two of us (KAP and PSU) cleaned the molars with cotton swabs soaked in alcohol and made impressions using President's Jet Regular Body Dental Impression Material (Coltene-Whaledent). High-resolution cast replicas were scanned by JD using a Pl $\mu$ Neox (Sensofar) scanning confocal profiler with white light and a 100 objective. Detailed analytical protocols are available in Scott et al. (2005) and Ungar et al. (2007).

The field of view of the scanning confocal microscope with the 100 objective is $127.32 \mu \mathrm{m}$ by $95.45 \mu \mathrm{m}$ with an $\mathrm{x}-\mathrm{y}$ spacing of $0.17 \mu \mathrm{m}$ and a vertical step interval of $0.2 \mu \mathrm{m}$. The published vertical resolution of the instrument is less than $1 \mathrm{~nm}$. Scans were taken of four quadrants and stitched together, with spikes and artifacts deleted, using SensoMap Premium Software (MountainsMap 7, DigitalSurf). The SensoMap scalesensitive fractal analysis module (formerly in Sfrax and ToothFrax software) generated surface texture data. These data were ranktransformed prior to analysis since microwear texture data typically violate the assumption of distribution normality (Ungar et al., 2007).

We used scale sensitive fractal analysis (SSFA) to test our hypotheses. It produces variables to characterize surface complexity, heterogeneity of complexity, scale of maximum complexity and other attributes (Ungar et al., 2003; Scott et al., 2006) proven effective at separating species by diet, including hard versus tough feeding carnivorans (Schubert et al., 2010; Ungar et al., 2010; DeSantis et al., 2012, 2013). Asfc (Area scale fractal complexity) measures complexity. This represents change in surface roughness with scale of observation. A surface dominated by a range of pit sizes and shapes is complex and suggests comminution of hard brittle foods, like bone (e.g., Tanis et al., 2018).

Heterogeneity addresses surface texture uniformity by considering variance in complexity across the surface divided into $3 \quad 3$ (HAsfc9) and 99 (HAsfc81) grids and can be used to distinguish between hard feeders (Scott et al., 2006). Prey size variance has been associated with increased heterogeneity (Schubert et al., 2010). The scale of maximum complexity, $S m f c$, is the scale at which surface roughness begins to decline. High $S m f c$ values indicate a surface either dominated by deep features at coarse scales or lacking many features at fine scales. Higher $S m f c$ correlates with higher wear resulting from the consumption of hard, brittle foods, such as bone. We ran MANOVA tests for these variables, with separate tests for the $\mathrm{M}_{1}$ and $\mathrm{M}_{2}$. ANOVAs for individual
Table 4

ANOVA of $\mathrm{M}_{2}$ from Predmostí canids previously identified as either Paleolithic dog or Pleistocene wolf by Germonpre et al. (2015a). Errors noted in parentheses; df 1, 18. See Supplementary Material A for raw data.

\begin{tabular}{lllll}
\hline & Asfc & Smfc & HAsfc9 & HAsfc81 \\
\hline Type II sum of & 9.8 & 186.05 & 8.45 & $33.8(631.2)$ \\
squares & $(655.2)$ & $(446.95)$ & $(656.05)$ & \\
Mean squared & $9.8(36.4)$ & 186.05 & 8.45 & 33.8 \\
& & $(24.831)$ & $(36.447)$ & $(35.067)$ \\
F-ratio & 0.269 & 7.493 & 0.232 & 0.964 \\
p-value & 0.61 & 0.014 & 0.636 & 0.339 \\
\hline
\end{tabular}

variables were used to determine the source(s) of significant variation between groups.

\section{Results and discussion}

\section{1. $M_{1}$ (carnassial)}

Raw data are provided in Supplement A. Summary statistics for the $M_{1}$ (n 19) can be found in Table 2. No variation between samples was observed for SSFA variables. Results of MANOVA statistics (Table 3) did not show any significant differences between these two canid samples. We expected that wolves and dogs would similarly use their carnassial teeth for shearing tough food (i.e., meat). Differences in hard-object consumption by canids are expected to manifest instead on the $\mathrm{M}_{2} \mathrm{~S}$ given the functional division of labor between carnassials and postcarnassial molars (Ungar et al., 2010).

\section{2. $M_{2}$ (post-carnassial)}

Raw data are provided in Supplement A. Summary statistics for the $\mathrm{M}_{2}$ (n 20) can be found in Table 2. Results of MANOVA statistics (Table 3) reveal significant differences between morphotypes. We used ANOVA to determine variance origins and Type II SS (sum of squares) to test for differences in central tendency between samples (Table 4). Only $S m f c$ clearly separated wolves from protodogs, with higher average values (i.e., fewer specimens with smaller features) observed in protodogs (Fig. 3). Surfaces dominated by small microwear features produce low $S m f c$ values. Protodogs exhibit a broader range of $S m f c$ values (Table 4) which is consistent with larger average feature size (e.g., pits) compared with wolves (Fig. 4).

\subsection{Interpretation}

Wolves and protodogs at Predmostí did not differ significantly on the $M_{1}$ carnassials, as would be expected with a diet of flesh. As for the $M_{2}$, the canid morphotypes did separate out significantly for $S m f c$. Higher $S m f c$ values for protodogs suggest a lack of small microwear features (or dominance of larger ones), consistent with a greater reliance on hard, brittle foods, such as bone.

The results are not directly comparable to previous microwear texture studies of modern and fossil canids (Ungar et al., 2010; DeSantis et al., 2015) because a newer generation instrument was used to generate the data. The new instrument has smaller point spacing, better vertical resolution, and field-of-view stitching, allowing a larger work

Table 3

$\mathrm{M}_{1}$ and $\mathrm{M}_{2}$ MANOVA for Predmostí canids previously identified as either Paleolithic dog or Pleistocene wolf by Germonpre et al. (2015a). See Supplementary Material A for raw data.

\begin{tabular}{|c|c|c|c|c|c|c|}
\hline & & & & Wilks's Lambda & Pillai Trace & Hotelling-Lawley Trace \\
\hline $\begin{array}{l}\mathrm{M}_{1} \\
\text { F-ratio }\end{array}$ & $0.323, \mathrm{df}$ & $4,14, \mathrm{p}$ & 0.963 & 0.961 & 0.039 & 0.041 \\
\hline $\mathrm{M}_{2}$ & & & & 0.477 & 0.523 & 1.096 \\
\hline
\end{tabular}




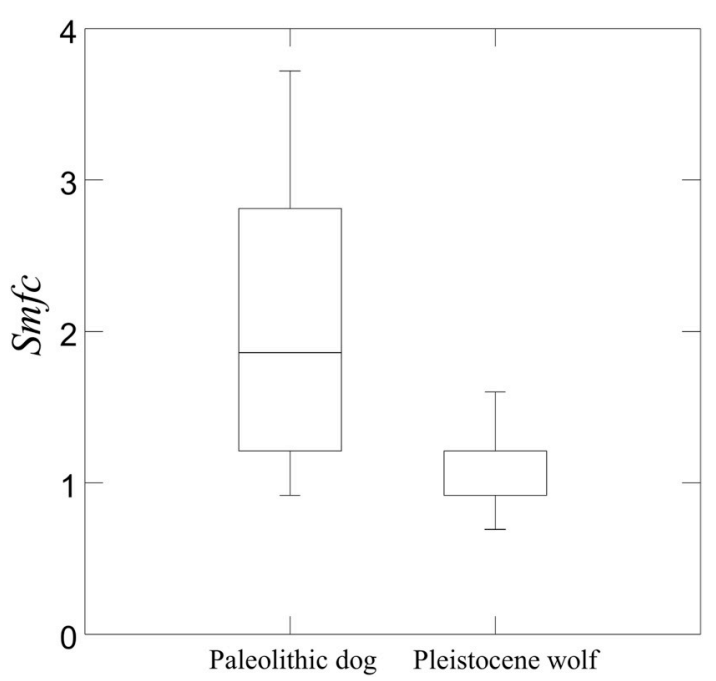

Fig. 3. Scale of Maximum Complexity ( $S m f c$ ) on $\mathrm{M}_{2}$ for Predmostí canids previously identified as either Paleolithic dog (n 10) or Pleistocene wolf (n 10) by Germonpre et al. (2015a). Whiskers represent the range of $S m f c$ values. See Supplementary Material A for raw data.

envelop. Filters can be applied to "homogenize" datasets across instruments and allow a measure of comparability (Arman et al., 2016), but we prefer to avoid any loss of diet "signal" associated with filtering given the expected subtly of differences between samples studied here. That said, the fundamental characteristics of microwear patterning on dentition and the variables tested remain the same.

In Ungar et al. (2010), coyote (Canis latrans) and African wild dog (Lycaon pictus) were compared and shown to exhibit higher pitting with higher complexity and lower anistropy values on their $\mathrm{M}_{2} \mathrm{~s}$ compared to their $\mathrm{M}_{1} \mathrm{~s}$ as is expected due to the biomechanics of canid mastication and the use of post-carnassials for crunching. DeSantis et al. (2015) includes specimens from Ungar et al. (2010), additional specimens of $L$. pictus, and specimens of grey wolf (Canis lupus) and found that while all evinced some bone comminution, C. lupus microwear reflected lower levels of bone consumption than the other canids. This is consistent with what is known of wolf, compared to coyote and African wild dog feeding behavior. Coyotes are more opportunistic, completely consuming smaller animals (Schmitt and Juell, 1994), while African wild dogs are more specialized, but under intense competition with lions and hyenas and known to more effectively consume carcasses (Van Valkenburgh, 1996; Carbone et al., 2005; contra Yravedra et al., 2014 which looked at captive wild dogs).

\section{Conclusion}

Morphological (Pokorný, 1951; Benecke, 1994; Germonpre et al., 2012, 2015a) and isotopic (Bocherens et al., 2015) data supports the presence of two distinct populations of Canis at Predmostí. These canids were identified by Germonpre et al. (2012) as Paleolithic dogs and Pleistocene wolves, though not without debate (e.g., Crockford and Kuzmin, 2012; Boudadi-Maligne and Escarguel, 2014; Morey, 2014; Perri, 2016). Here, behavioral trace differences associated with bone consumption further supports the separation of these canids into two distinct populations. Specifically, our dental microwear texture analysis results are consistent with the protodog (Paleolithic dog) morphotype as a greater consumer of more hard brittle foods, interpreted here as bone.

Isotope analysis suggests wolves and humans focused on mammoth, while dogs and lions focused on reindeer and other prey (Bocherens et al., 2015). Protodogs fed scraps would have been better able to break and consume the bones of reindeer and smaller prey compared to mammoths, and this may help explain the signal. Alternatively, protodogs may have opportunistically scavenged off felid kills, as felids typically leave more flesh as well as marrow containing bones than do canids or hyaenids (Blumenschine, 1987; Parkinson et al., 2015). That

A
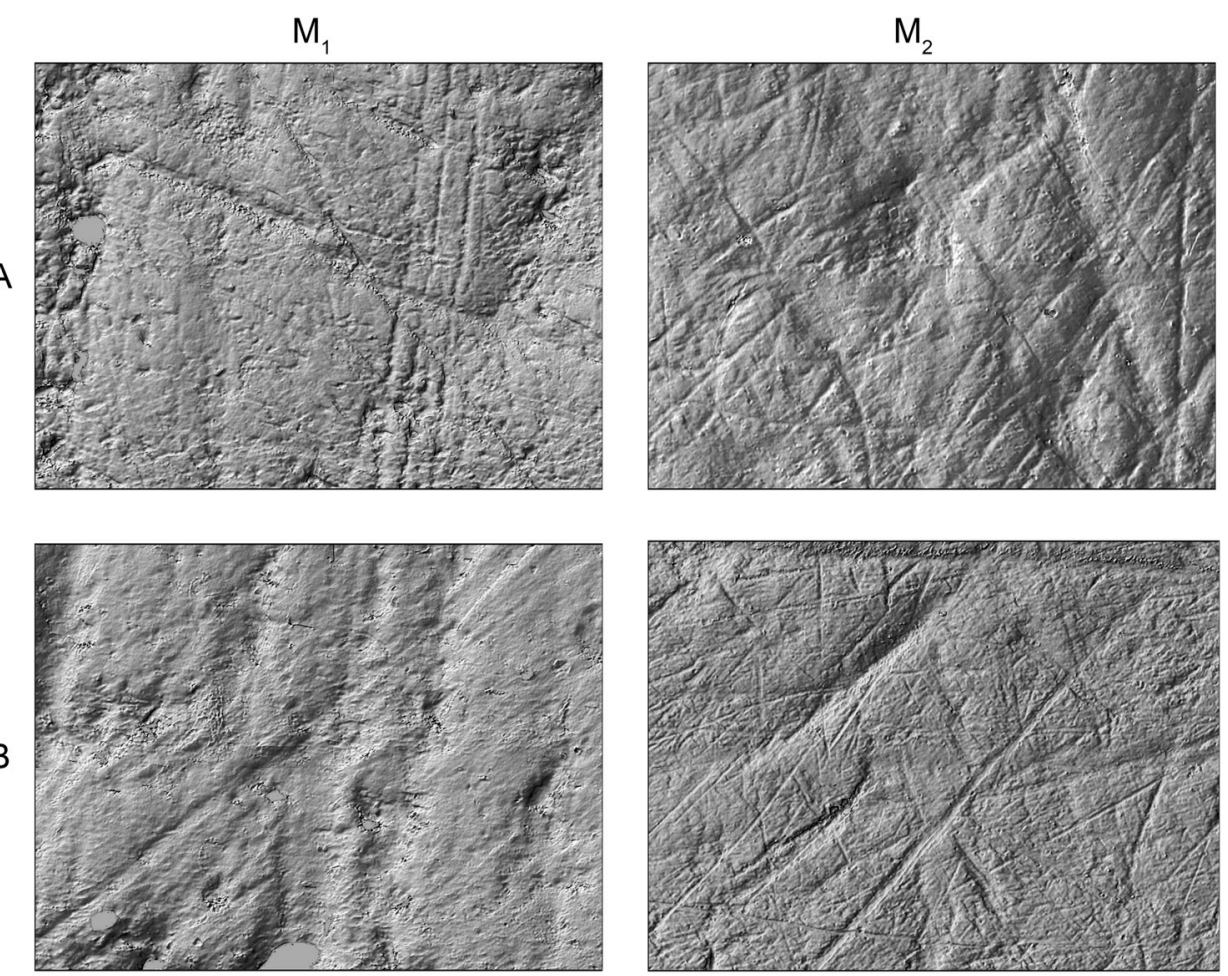

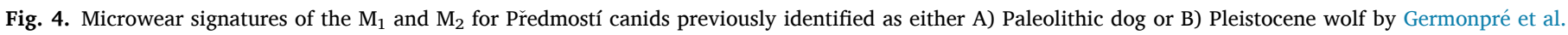

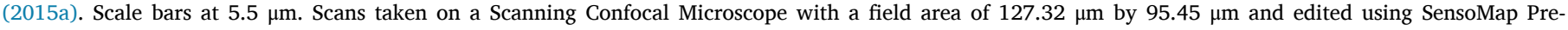
mium software. 
said, this combined evidence does not refute the possibility that these represent two wolf populations that differed in both morphology and dietary behavior (prey selection and, as noted here, level of bone consumption) in response to increased competition or environmental change, as argued by Perri (2016).

Wolf dietary behavior can vary across time (Flower and Schreve, 2014) and environment (see Schweizer et al., 2016 and references therein), with related morphological (Slater et al., 2009), isotopic (Pilot et al., 2012), and genetic (Nowak and Federoff, 2002; Ciucani et al., 2019; Schweizer et al., 2016) differences evident. Such variance can occur even between geographically close populations, such as seen with wolves from coastal (Darimont et al., 2003) and inland (Muñoz-Fuentes et al., 2009) British Colombia. It is possible then that these are two morphologically and behaviorally distinct wolf populations that overlapped in territory, at least on a seasonal basis, as is seen in wolf populations today (Wilson et al., 2000). In the archaeological record, this could be time averaged to suggest sympatry. Nonetheless, we provide an additional line of evidence that supports the interpretation of two morphologically and behaviorally distinct canid populations co-occurring at Predmostí during the periods of permanent (Nývltova Fisakova, 2013) human site occupation.

Why some wolves integrated into human society is unknown, but canids could have fulfilled many functions in the daily life of Upper Paleolithic peoples (Shipman, 2015; Lupo, 2017; Germonpre et al., 2018). Their utility as hunting and working aids, protectors, companions, and food remain reasons for this relationship today. Our intent was not to address these questions but rather to provide an additional, independent line of evidence to identify the early behavioral shift in wolves potentially associated with early domestication of another animal by Homo sapiens. These results suggest the need for additional studies, both at Predmostí and at other prehistoric dog sites, to help to confirm or refute the presence of distinct canid types and to elucidate their roles in other prehistoric societies. For example, North American Great Plains dogs and wolves are often indistinguishable morphologically, but maize consumption by dogs can allow for separation isotopically (Fisher, 2019). Starch diets are also purported for Neolithic dogs, with high copy numbers of the starch emulsifying AMY2B enzyme in dogs following the spread of agriculture (Arendt et al., 2016). A diet rich in starches will produce distinct microwear (Schmidt, 2001) that could provide insight into dog's place in prehistoric agricultural societies. Analyses of feral village dogs, dingoes, dholes and additional modern analogue studies of coyotes, African wild dogs, and wolves would be useful both for strengthening the link between diet and microwear in canids and to address how changes in diet from historic to modern canids relate to increased anthropogenic effects on habitat patchiness, prey decline, and competition for resources.

\section{Funding}

This paper was supported by a grant from the Czech Science Foundation, GACR GA15-06446S "The relationships between humans and large canids - the dogs and wolves - of the Gravettian Predmostí site (Moravia)" and by the Ministry of Culture of the Czech Republic by institutional financing of long-term conceptual development of the research institution (the Moravian Museum, MK000094862). The University of Arkansas Honors College funded PSU and JD. KAP received no financial support from the National Park Service for this study and her contributions do not necessarily reflect the opinions or policies of, the National Park Service.

\section{Acknowledgement}

KAP and PSU thank Martina Roblíckova at the Moravian Museum for her hospitality and in providing us access to the Predmostí specimens used in this study.

\section{Appendix A. Supplementary data}

Supplementary data to this article can be found online at https://doi. org/10.1016/j.jas.2020.105092.

\section{References}

Ameen, C., Hulme-Beaman, A., Evin, A., Germonpre, M., Britton, K., Cucchi, T., Larson, G., Dobney, K., 2017. A landmark-based approach for assessing the reliability of mandibular tooth crowding as a marker of dog domestication. J. Archaeol. Sci. 85, 41-50. https://doi.org/10.1016/j.jas.2017.06.014.

Andres, M., Gidna, A.O., Yravedra, J., Domínguez-Rodrigo, M., 2012. A study of dimensional differences of tooth marks (pits and scores) on bones modified by small and large carnivores. Arch. Anthropol. Sci. 4 (3), 209-219. https://doi.org/10.1007/ s12520-012-0093-4.

Arendt, M., Cairns, K.M., Ballard, J.W.O., Savolainen, P., Axelsson, E., 2016. Diet adaptation in dog reflects spread of prehistoric agriculture. Heredity 117 (5), 301. https://doi.org/10.1038/hdy.2016.48.

Arman, S.D., Ungar, P.S., Brown, C.A., DeSantis, L.R.G., Schmidt, C., Prideaux, G.J., 2016. Minimizing inter-microscope variability in dental microwear texture analysis, Surf. Topogr. Metrol. Prop. 4 (2), 24007.

Atici, A.L., 2006. Who let the dogs out? Bone destruction and its broader implications in interpreting the Bronze Age pastoral economies at Kaman-Kalehoyük. Anatol. Archaeol. Stud. 15, 121-131.

Bastl, K., Semprebon, G., Nagel, D., 2012. Low-magnification microwear in Carnivora and dietary diversity in Hyaenodon (Mammalia: Hyaenodontidae) with additional information on its enamel microstructure. Palaeogeogr. Palaeoclimatol. Palaeoecol. 348, 13-20. https://doi.org/10.1016/j.palaeo.2012.05.026.

Bateman, P.W., Fleming, P.A., 2012. Big city life: carnivores in urban environments. J. Zool. 287 (1), 1-23. https://doi.org/10.1111/j.1469-7998.2011.00887.x.

Benecke, N., 1987. Studies on early dog remains from Northern Europe. J. Archaeol. Sci. 14, 31-49. https://doi.org/10.1016/S0305-4403(87)80004-3.

Benecke, N., 1994. Archaozoologische Studien zur Entwicklung der Haustierhaltung. Akademie Verlag, Berlin.

Biknevicus, A.R., Van Valkenburgh, B., Gittleman, J.L., 1996. Design for killing: craniodental adaptations of predators. In: Gittleman, J.L. (Ed.), Carnivore Behavior Ecology and Evolution. Cornell University Press, Ithaca, New York, pp. 393-428.

Blumenschine, R.J., 1987. Characteristics of an early hominid scavenging niche. Curr. Anthropol. 28 (4), 383-407. https://doi.org/10.1086/203544.

Botigue, L.R., Song, S., Scheu, A., Gopalan, S., Pendleton, A.L., Oetjens, M., Taravella, A. M., Seregely, T., Zeeb-Lanz, A., Arbogast, R.M., Bobo, D., 2017. Ancient European dog genomes reveal continuity since the Early Neolithic. Nat. Commun. 8, 16082 https://doi.org/10.1038/ncomms16082.

Bocherens, H., Drucker, D.G., Germonpre, M., Laznickova-Galetova, M., Naito, Y.I., Wissing, C., Brůzek, J., Oliva, M., 2015. Reconstruction of the Gravettian food-web at Predmostí I using multi-isotopic tracking $\left({ }^{13} \mathrm{C},{ }^{15} \mathrm{~N},{ }^{34} \mathrm{~S}\right)$ of bone collagen. Quat. Int. 359, 211-228. https://doi.org/10.1016/j.quaint.2014.09.044.

Boudadi-Maligne, M., Mallye, J.B., Langlais, M., Barshay-Szmidt, C., 2012. Magdalenian dog remains from Le Morin rockshelter (Gironde, France). Socio-economic implications of a zootechnical innovation. PALEO Revue d'archeologie prehistorique 23, 39-54. http://journals.openedition.org/paleo/2465.

Boudadi-Maligne, M., Escarguel, G., 2014. A biometric re-evaluation of recent claims for Early Upper Palaeolithic wolf domestication in Eurasia. J. Archaeol. Sci. 45, 80-89. https://doi.org/10.1016/j.jas.2014.02.006.

Butler, J.R.A., Du Toit, J.T., 2002. February. Diet of free-ranging domestic dogs (Canis familiaris) in rural Zimbabwe: implications for wild scavengers on the periphery of wildlife reserves. An. Conserv. For. 5 (1), 29-37. https://doi.org/10.1017/ S136794300200104X.

Camaros, E., Münzel, S.C., Cueto, M., Rivals, F., Conard, N.J., 2016. The evolution of Paleolithic hominin-carnivore interaction written in teeth: Stories from the Swabian Jura (Germany). J. Archaeol. Sci. 6, 798-809. https://doi.org/10.1016/j. jasrep.2015.11.010.

Caporale, S.S., Ungar, P.S., 2016. Rodent incisor microwear as a proxy for ecological reconstruction. Palaeogeogr. Palaeoclimatol. Palaeoecol. 446, 225-233. https://doi. org/10.1016/j.palaeo.2016.01.013.

Carbone, C., Frame, L., Frame, G., Malcolm, J., Fanshawe, J., FitzGibbon, C., Schaller, G., Gordon, I.J., Rowcliffe, J.M., Du Toit, J.T., 2005. Feeding success of African wild dogs (Lycaon pictus) in the Serengeti: the effects of group size and kleptoparasitism. J. Zool. 266 (2), 153-161. https://doi.org/10.1017/S0952836905006710.

Chaix, L., 2000. A preboreal dog from the northern Alps (Savoie, France). In: Crockford, S.J. (Ed.), Dogs through Time: an Archaeological Perspective. Proceedings of the First ICAZ Symposium on the History of the Domestic Dog (1998. Canada), pp. 49-60.

Ciucani, M.M., Palumbo, D., Galaverni, M., Serventi, P., Fabbri, E., Ravegnini, G., Angelini, S., Maini, E., Persico, D., Caniglia, R., Cilli, E., 2019. Old wild wolves: ancient DNA survey unveils population dynamics in Late Pleistocene and Holocene Italian remains. PeerJ 7, e6424. https://doi.org/10.7717/peerj.6424.

Clutton-Brock, J., 1995. Origins of the dog: domestication and early history. In: Serpell, J. (Ed.), The Domestic Dog: its Evolution, Behaviour and Interactions with People. Cambridge University Press, pp. 7-20.

Clutton-Brock, J., 2016. Origins of the dog: the archaeological evidence. In: Serpell, J. (Ed.), The Domestic Dog: its Evolution, Behavior and Interactions with People. Cambridge University Press, pp. 7-21. 
Coard, R., 2007. Ascertaining an agent: using tooth pit data to determine the carnivore/s responsible for predation in cases of suspected big cat kills in an upland area of Britain. J. Archaeol. Sci. 34 (10), 1677-1684. https://doi.org/10.1016/j. jas.2006.12.006.

Conard, N.J., Bolus, M., 2008. Radiocarbon dating the late middle paleolithic and the Aurignacian of the Swabian Jura. J. Hum. Evol. 55 (5), 886-897. https://doi.org/ 10.1016/j.jhevol.2008.08.006.

Coppinger, R., Coppinger, L., 2001. Dogs: A Startling New Understanding of Canine Origin, Behavior, and Evolution. University of Chicago Press.

Crockford, S.J., Kuzmin, Y.V., 2012. Comments on Germonpre et al., Journal of Archaeological Science 36, 2009 "Fossil dogs and wolves from Palaeolithic sites in Belgium, the Ukraine and Russia: osteometry, ancient DNA and stable isotopes", and Germonpre, Lazkickova-Galetova, and Sablin, Journal of Archaeological Science 39, 2012 "Palaeolithic dog skulls at the Gravettian Predmostí site, the Czech Republic". J. Archaeol. Sci. 39 (8), 2797-2801. https://doi.org/10.1016/j.jas.2012.04.033.

Darimont, C.T., Reimchen, T.E., Paquet, P.C., 2003. Foraging behaviour by gray wolves on salmon streams in coastal British Columbia. Can. J. Zool. 81 (2), 349-353. https://doi.org/10.1139/z02-246.

Davis, S.J., Valla, F.R., 1978. Evidence for domestication of the dog 12,000 years ago in the Natufian of Israel. Nature 276 (5688), 608. https://doi.org/10.1038/276608a0.

Degerbøl, M., 1961. On a find of a Preboreal domestic dog (Canis familiaris) from Star Carr, Yorkshire, with remarks on other Mesolithic dogs. Proc. Prehist. Soc. 28, 33-55. https://doi.org/10.1017/S0079497X0001598X.

Delaney-Rivera, C., Plummer, T.W., Hodgson, J.A., Forrest, F., Hertel, F., Oliver, J.S., 2009. Pits and pitfalls: taxonomic variability and patterning in tooth mark dimensions. J. Archaeol. Sci. 36 (11), 2597-2608. https://doi.org/10.1016/j. jas.2009.08.001.

DeSantis, L.R.G., Schubert, B.W., Scott, J.R., Ungar, P.S., 2012. Implications of diet for the extinction of sabertoothed cats and American lions. PloS One 7, e52453. https:// doi.org/10.1371/journal.pone.0052453.

DeSantis, L.R., Scott, J.R., Schubert, B.W., Donohue, S.L., McCray, B.M., Van Stolk, C.A., Winburn, A.A., Greshko, M.A., O'Hara, M.C., 2013. Direct comparisons of 2D and 3D dental microwear proxies in extant herbivorous and carnivorous mammals. PloS One 8 (8), e71428. https://doi.org/10.1371/journal.pone.0071428.

DeSantis, L.R., Haupt, R.J., 2014. Cougars' key to survival through the Late Pleistocene extinction: insights from dental microwear texture analysis. Biol. Lett. 10, 20140203. https://doi.org/10.1098/rsbl.2014.0203.

DeSantis, L.R., Schubert, B.W., Schmitt-Linville, E., Ungar, P.S., Donohue, S.L., Haupt, R. J., 2015. Dental microwear textures of carnivorans from the La Brea Tar Pits, California, and potential extinction implications. Contrib. Sci. LACMNH 42, 37-52.

DeSantis, L.R., 2016. Dental microwear textures: reconstructing diets of fossil mammals. Surf. Topogr. Metrol. Prop. 4 (2), 023002. http://doi:10.1088/2051-672X/4/2/02 3002.

Dominguez-Rodrigo, M., Piqueras, A., 2003. The use of tooth pits to identify carnivore taxa in tooth-marked archaeofaunas and their relevance to reconstruct hominid carcass processing behaviours. J. Archaeol. Sci. 30 (11), 1385-1391. https://doi. org/10.1016/S0305-4403(03)00027-X.

Donohue, S.L., DeSantis, L.R., Schubert, B.W., Ungar, P.S., 2013. Was the giant shortfaced bear a hyper-scavenger? A new approach to the dietary study of ursids using dental microwear textures. PloS One 8 (10), e77531. https://doi.org/10.1371/ journal.pone.0077531.

Drake, A.G., Coquerelle, M., Colombeau, G., 2015. 3D morphometric analysis of fossil canid skulls contradicts the suggested domestication of dogs during the late Paleolithic. Sci. Rep. 5, 8299. https://doi.org/10.1038/srep08299.

Druzhkova, A.S., Thalmann, O., Trifonov, V.A., Leonard, J.A., Vorobieva, N.V., Ovodov, N.D., Graphodatsky, A.S., Wayne, R.K., 2013. Ancient DNA analysis affirms the canid from Altai as a primitive dog. PloS One 8 (3), e57754. https://doi.org/ 10.1371/journal.pone.0057754.

Ersmark, E., Klütsch, C.F., Chan, Y.L., Sinding, M.H.S., Fain, S.R., Illarionova, N.A., Oskarsson, M., Uhlen, M., Zhang, Y.P., Dalen, L., Savolainen, P., 2016. From the past to the present: wolf phylogeography and demographic history based on the mitochondrial control region. Front. Ecol. Evol. 4, 134. https://doi.org/10.3389/ fevo.2016.00134.

Fisher, A.E., 2019. When is a wolf a dog? Combined geometric morphometrics and stable isotope analyses for differentiating wild from domestic canids on the Northern Plains. Plains Anthropol. 1-34. https://doi.org/10.1080/00320447.2018.1548064.

Flower, L.O., Schreve, D.C., 2014. An investigation of palaeodietary variability in European Pleistocene canids. Quat. Sci. Rev. 96, 188-203. https://doi.org/10.1016/ j.quascirev.2014.04.015.

Flower, L.O.H., 2016. New body mass estimates of British Pleistocene wolves: palaeoenvironmental implications and competitive interactions. Quat. Sci. Rev. 149, 230-247. https://doi.org/10.1016/j.quascirev.2016.07.023.

Forsyth, D.M., Woodford, L., Moloney, P.D., Hampton, J.O., Woolnough, A.P., Tucker, M., 2014. How does a carnivore guild utilize a substantial but unpredictable anthropogenic food source? Scavenging on hunter-shot ungulate carcasses by wild dogs/dingoes, red foxes and feral cats in south-eastern Australia revealed by camera traps. PloS One 9 (6), e97937. https://doi.org/10.1371/journal.pone.0097937.

Frantz, L.A., Mullin, V.E., Pionnier-Capitan, M., Lebrasseur, O., Ollivier, M., Perri, A., Linderholm, A., Mattiangeli, V., Teasdale, M.D., Dimopoulos, E.A., Tresset, A., 2016. Genomic and archaeological evidence suggest a dual origin of domestic dogs. Science 352 (6290), 1228-1231. https://doi.org/10.1126/science.aaf3161.

Freedman, A.H., Gronau, I., Schweizer, R.M., Ortega-Del Vecchyo, D., Han, E., Silva, P. M., Galaverni, M., Fan, Z., Marx, P., Lorente-Galdos, B., Beale, H., 2014. Genome sequencing highlights the dynamic early history of dogs. PLoS Genet. 10 (1), e1004016 https://doi.org/10.1371/journal.pgen.1004016.
Galibert, F., Quignon, P., Hitte, C., Andre, C., 2011. Toward understanding dog evolutionary and domestication history. Comptes Rendus Biol. 334 (3), 190-196. https://doi.org/10.1016/j.crvi.2010.12.011.

Germonpre, M., Sablin, M.V., Stevens, R.E., Hedges, R.E., Hofreiter, M., Stiller, M., Despres, V.R., 2009. Fossil dogs and wolves from Palaeolithic sites in Belgium, the Ukraine and Russia: osteometry, ancient DNA and stable isotopes. J. Archaeol. Sci. 36 (2), 473-490. https://doi.org/10.1016/j.jas.2008.09.033.

Germonpre, M., Laznickova-Galetova, M., Sablin, M.V., 2012. Palaeolithic dog skulls at the Gravettian Predmostí site, the Czech Republic. J. Archaeol. Sci. 39 (1), 184-202. https://doi.org/10.1016/j.jas.2011.09.022.

Germonpre, M., Laznickova-Galetova, M., Losey, R.J., Raikkonen, J., Sablin, M.V., 2015a. Large canids at the Gravettian Predmostí site, the Czech Republic: the mandible. Quat. Int. 359, 261-279. https://doi.org/10.1016/j.quaint.2014.07.012.

Germonpre, M., Sablin, M.V., Laznickova-Galetova, M., Despres, V., Stevens, R.E., Stiller, M., Hofreiter, M., 2015b. Palaeolithic dogs and Pleistocene wolves revisited: a reply to Morey (2014). J. Archaeol. Sci. 54, 210-216. https://doi.org/10.1016/j. jas.2014.11.035.

Germonpre, M., Laznickova-Galetova, M., Jimenez, E.L., Losey, R., Sablin, M., Bocherens, H., Van Den Broeck, M., 2017a. Consumption of canid meat at the Gravettian Predmostí site, the Czech Republic. Fossil Imprint 73 (3-4), 360-382. https://doi.org/10.1016/j.quaint.2014.07.012.

Germonpre, M., Fedorov, S., Danilov, P., Galeta, P., Jimenez, E.L., Sablin, M., Losey, R.J., 2017b. Palaeolithic and prehistoric dogs and Pleistocene wolves from Yakutia: identification of isolated skulls. J. Archaeol. Sci. 78, 1-19. https://doi.org/10.1016/ j.jas.2016.11.008.

Germonpre, M., Laznickova-Galetova, M., Sablin, M.V., Bocherens, H., 2018. Selfdomestication or human control? The Upper Palaeolithic domestication of the dog. In: Vigne, J.D., Stepanoff, C. (Eds.), Rethinking Domestication: Biosocial Approaches to Hybrid Communities. Routledge, London, pp. 39-64.

Goillot, C., Blondel, C., Peigne, S., 2009. Relationships between dental microwear and diet in Carnivora (Mammalia) - implications for the reconstruction of the diet of extinct taxa. Palaeogeogr. Palaeoclimatol. Palaeoecol. 271 (1-2), 13-23. https://doi. org/10.1016/j.palaeo.2008.09.004.

Gray, M.M., Sutter, N.B., Ostrander, E.A., Wayne, R.K., 2010. The IGF1 small dog haplotype is derived from Middle Eastern grey wolves. BMC Biol. 8 (1), 16. https:// doi.org/10.1186/1741-7007-8-16.

Grayson, D.K., Parmalee, P.W., Lyman, R.L., Mead, J.I., 1988. Danger cave, Last supper cave, and hanging rock Shelter: the faunas. Anthropol. Pap. AMNH 66 (1).

Grine, F.E., 1986. Dental evidence for dietary differences in Australopithecus and Paranthropus: a quantitative analysis of permanent molar microwear. J. Hum. Evol. 15 (8), 783-822. https://doi.org/10.1016/S0047-2484(86)80010-0.

Horwitz, L.K., 1990. The origin of partially digested bones recovered from archaeological contexts in Israel. Paleorient 97-106.

Janssens, L., Spanoghe, I., Miller, R., Van Dongen, S., 2016. Can orbital angle morphology distinguish dogs from wolves? Zoomorphology 135 (1), 149-158. https://doi.org/10.1007/s00435-015-0294-3.

Janssens, L., Giemsch, L., Schmitz, R., Street, M., Van Dongen, S., Crombe, P., 2018. A new look at an old dog: Bonn-Oberkassel reconsidered. J. Archaeol. Sci. 92, 126-138. https://doi.org/10.1016/j.jas.2018.01.004.

Janssens, L., Perri, A., Crombe, P., Van Dongen, S., Lawler, D., 2019. An evaluation of classical morphologic and morphometric parameters reported to distinguish wolves and dogs. J. Archaeol. Sci. 23, 501-533. https://doi.org/10.1016/j. jasrep.2018.10.012.

Jung, C., Portl, D., 2018. Scavenging hypothesis: lack of evidence for dog domestication on the waste dump. Dog Behavior 4 (2), 41-56. https://doi.org/10.4454/db.v4i2.73.

King, T., Aiello, L.C., Andrews, P., 1999. Dental microwear of Griphopithecus alpani. J. Hum. Evol. 36 (1), 3-31. https://doi.org/10.1006/jhev.1998.0258.

Krueger, K.L., Scott, J.R., Kay, R.F., Ungar, P.S., 2008. Dental microwear textures of "Phase I" and "Phase II" facets. Am. J. Phys. Anthropol. 137 (4), 485-490. https:// doi.org/10.1002/ajpa.20928.

Kubo, M.O., Yamada, E., Kubo, T., Kohno, N., 2017. Dental microwear texture analysis of extant sika deer with considerations on inter-microscope variability and surface preparation protocols. Biosurf. Biotribol. 3 (4), 155-165. https://doi.org/10.1016/j. bsbt.2017.11.006.

Larson, G., Bradley, D.G., 2014. How much is that in dog years? The advent of canine population genomics. PLoS Genet. 10, e1004093 https://doi.org/10.1371/journal. pgen.1004093.

Larson, G., Karlsson, E.K., Perri, A., Webster, M.T., Ho, S.Y., Peters, J., Stahl, P.W., Piper, P.J., Lingaas, F., Fredholm, M., Comstock, K.E., 2012. Rethinking dog domestication by integrating genetics, archeology, and biogeography. Proc. Natl. Acad. Sci. Unit. States Am. 109 (23), 887-8883. https://doi.org/10.1073/ pnas. 1203005109.

Leonard, J.A., Wayne, R.K., Wheeler, J., Valadez, R., Guillen, S., Vila, C., 2002. Ancient DNA evidence for old world origin of new world dogs. Science 298, 1613-1616. https://doi.org/10.1126/science.1076980.

Leonard, J.A., Vila, C., Fox-Dobbs, K., Koch, P.L., Wayne, R.K., Van Valkenburgh, B., 2007. Megafaunal extinctions and the disappearance of a specialized wolf ecomorph. Curr. Biol. 17, 1146-1150. https://doi.org/10.1016/j.cub.2007.05.072.

Losey, R.J., McLachlin, K., Nomokonova, T., Latham, K., Harrington, L., 2015. Body mass estimates in dogs and North American gray wolves using limb element dimensions. Int. J. Osteoarchaeol. 27 (2), 180-191. https://doi.org/10.1002/oa.2528.

Losey, R.J., Jessup, E., Nomokonova, T., Sablin, M., 2014. Craniomandibular trauma and tooth loss in northern dogs and wolves: implications for the archaeological study of dog husbandry and domestication. PloS One 9 (6), e99746. https://doi.org/ 10.1371/journal.pone.0099746. 
Lupo, K.D., 2017. When and where do dogs improve hunting productivity? The empirical record and some implications for early Upper Paleolithic prey acquisition. J. Anthropol. Archaeol. 47, 139-151. https://doi.org/10.1016/j.jaa.2017.05.003.

Lyon, P.J., 1970. Differential bone destruction: an ethnographic example. Am. Antiq. 35 (2), 213-215.

Marsden, C.D., Ortega-Del Vecchyo, D., O’Brien, D.P., Taylor, J.F., Ramirez, O., Vila, C., Marques-Bonet, T., Schnabel, R.D., Wayne, R.K., Lohmueller, K.E., 2016. Bottlenecks and selective sweeps during domestication have increased deleterious genetic variation in dogs. Proc. Natl. Acad. Sci. Unit. States Am. 113 (1), 152-157. https:// doi.org/10.1073/pnas.1512501113.

Meachen, J.A., Brannick, A.L., Fry, T.J., 2016. Extinct Beringian wolf morphotype found in the continental US has implications for wolf migration and evolution. Ecol. Evol. 6 (10), 3430-3438. https://doi.org/10.1002/ece3.2141.

Merceron, G., Blondel, C., De Bonis, L., Koufos, G.D., Viriot, L., 2005. A new method of dental microwear analysis: application to extant primates and Ouranopithecus macedoniensis (Late Miocene of Greece). Palaios 20 (6), 551-561. https://doi.org/ 10.2110/palo.2004.p04-17.

Morey, D., 2010. Dogs: Domestication and the Development of a Social Bond. Cambridge University Press.

Morey, D.F., 2014. In search of Paleolithic dogs: a quest with mixed results. J. Archaeol Sci. 52, 300-307. https://doi.org/10.1016/j.jas.2014.08.015.

Morey, D.F., Jeger, R., 2015. Paleolithic dogs: why sustained domestication then? J. Archaeol. Sci. 3, 420-428. https://doi.org/10.1016/j.jasrep.2015.06.031.

Muñoz-Fuentes, V., Darimont, C.T., Wayne, R.K., Paquet, P.C., Leonard, J.A., 2009. Ecological factors drive differentiation in wolves from British Columbia. J. Biogeogr. 36 (8), 1516-1531. https://doi.org/10.1111/j.1365-2699.2008.02067.x.

Munson, P.J., 2000. Age-correlated differential destruction of bones and its effect on archaeological mortality profiles of domestic sheep and goats. J. Archaeol. Sci. 27, 391-407. https://doi.org/10.1006/jasc.1999.0463.

Murray, M., Cembrowski, A., Latham, A.D.M., Lukasik, V.M., Pruss, S., St Clair, C.C. 2015. Greater consumption of protein-poor anthropogenic food by urban relative to rural coyotes increases diet breadth and potential for human-wildlife conflict. Ecography 38 (12), 1235-1242. https://doi.org/10.1111/ecog.01128.

Musil, R., 2000. Evidence for the domestication of wolves in Central European Magdalenian sites. In: Crockford, S.J. (Ed.), Dogs through Time: an Archaeological Perspective. Archaeopress, Oxford, pp. 21-28.

Musil, R., 2008. The paleoclimatic and paleoenvironmental conditions at Predmostí. In: Velemínska, J., Bruzek, J. (Eds.), Early Modern Humans from Predmostí Near Prerov, Czech Republic. A New Reading of Old Documentation. Academia, Praha, pp. 15-20.

Napierala, H., Uerpmann, H.P., 2012. A 'new' Palaeolithic dog from central Europe. Int. J. Osteoarchaeol. 22 (2), 127-137. https://doi.org/10.1002/oa.1182.

Nobis, G., 1979. Der alteste HaushunNobis G. Der alteste Haushunde lebte vor 14000 Jahren [The oldest domestic dog lived 14,000 years ago.]. UMSCHAU WISSENSCH. TECH. 79 (19), 610.

Nowak, R.M., Federoff, N.E., 2002. The systematic status of the Italian wolf Canis lupus. Acta Theriol. 47, 333-338. https://doi.org/10.1007/BF03194151.

Nývltova Fisakova, M., 2013. Seasonality of gravettian sites in the middle Danube region and adjoining areas of central Europe. Quat. Int. 294, 120e134.

O'Keefe, F.R., Meachen, J., Fet, E.V., Brannick, A., 2013. Ecological determinants of clinal morphological variation in the cranium of the North American gray wolf. J. Mammal. 94 (6), 1223-1236. https://doi.org/10.1644/13-MAMM-A-069.

Outram, A.K., Stear, N.A., Bendrey, R., Olsen, S., Kasparov, A., Zaibert, V., Thorpe, N., Evershed, R.P., 2009. The earliest horse harnessing and milking. Science 323 (5919), 1332-1335. https://doi.org/10.1126/science.1168594.

Ovodov, N.D., Crockford, S.J., Kuzmin, Y.V., Higham, T.F., Hodgins, G.W., van der Plicht, J., 2011. A 33,000-year-old incipient dog from the Altai Mountains of Siberia: evidence of the earliest domestication disrupted by the Last Glacial Maximum. PloS One 6 (7), e22821. https://doi.org/10.1371/journal.pone.0022821.

Pang, J.F., Kluetsch, C., Zou, X.J., Zhang, A.B., Luo, L.Y., Angleby, H., Ardalan, A., Ekstrom, C., Skollermo, A., Lundeberg, J., Matsumura, S., 2009. mtDNA data indicate a single origin for dogs south of Yangtze River, less than 16,300 years ago, from numerous wolves. Mol. Biol. Evol. 26 (12), 2849-2864. https://doi.org/ 10.1093/molbev/msp195.

Parkinson, J.A., Plummer, T., Hartstone-Rose, A., 2015. Characterizing felid tooth marking and gross bone damage patterns using GIS image analysis: an experimental feeding study with large felids. J. Hum. Evol. 80, 114-134. https://doi.org/10.1016/ j.jhevol.2014.10.011.

Pendleton, A.L., Shen, F., Taravella, A.M., Emery, S., Veeramah, K.R., Boyko, A.R. Kidd, J.M., 2018. Comparison of village dog and wolf genomes highlights the role of the neural crest in dog domestication. BMC Biol. 16 (1), 64. https://doi.org/ 10.1186/s12915-018-0535-2.

Perri, A., 2016. A wolf in dog's clothing: initial dog domestication and Pleistocene wolf variation. J. Archaeol. Sci. 68, 1-4. https://doi.org/10.1016/j.jas.2016.02.003.

Perri, A., Widga, C., Lawler, D., Martin, T., Loebel, T., Farnsworth, K., Kohn, L., Buenger, B., 2019. New evidence of the earliest domestic dogs in the Americas. Am. Antiq. 84 (1), 68-87. https://doi.org/10.1017/aaq.2018.74.

Pidoplichko, I.G., 1998. Upper Palaeolithic dwellings of mammoth bones in the Ukraine, 712. BAR International Series.

Pilot, M., Greco, C., vonHoldt, B.M., Jedrzejewska, B., Randi, E., Jedrzejewski, W., Sidorovich, V.E., Ostrander, E.A., Wayne, R.K., 2014. Genome-wide signatures of population bottlenecks and diversifying selection in European wolves. Heredity 112, 428-442. https://doi.org/10.1038/hdy.2013.122.

Pilot, M., Jędrzejewski, W., Sidorovich, V.E., Meier-Augenstein, W., Hoelzel, A.R., 2012. Dietary differentiation and the evolution of population genetic structure in a highly mobile carnivore. PloS One 7 (6), e39341. https://doi.org/10.1371/journal. pone.0039341.

Pokorný, M., 1951. Príspevek k paleontologii diluvia v Predmostí u Prerova. Acta Musei Moraviae 36, 33-52.

Popowics, T.E., 2003. Postcanine dental form in the Mustelidae and viverridae (Carnivora: Mammalia). J. Morphol. 256 (3), 322-341. https://doi.org/10.1002/ jmor.10091.

Purnell, M.A., Crumpton, N., Gill, P.G., Jones, G., Rayfield, E.J., 2013. Within-guild dietary discrimination from 3-D textural analysis of tooth microwear in insectivorous mammals. J. Zool. 291 (4), 249-257. https://doi.org/10.1111/jzo.12068.

Rossel, S., Marshall, F., Peters, J., Pilgram, T., Adams, M.D., O' Connor, D., 2008. Domestication of the donkey: timing, processes, and indicators. Proc. Natl. Acad. Sci. Unit. States Am. 105 (10), 3715-3720. https://doi.org/10.1073/pnas.0709692105.

Russell, N., Twiss, K.C., 2017. Digesting the data: dogs as taphonomic agents at Neolithic Catalhoyük, Turkey. In: Mashkour, M., Beech, M. (Eds.), Archaeozoology of the Near East 9. International Council of Archaeozoology (ICAZ), pp. 59-75.

Sablin, M., Khlopachev, G., 2002. The earliest Ice Age dogs: evidence from Eliseevichi. Curr. Anthropol. 43 (50), 795-799. https://doi.org/10.1086/344372.

Sacco, T., Van Valkenburgh, B., 2004. Ecomorphological indicators of feeding behaviour in the bears (Carnivora: Ursidae). J. Zool. 263 (1), 41-54. https://doi.org/10.1017/ S0952836904004856.

Sansalone, G., Berte, D.F., Maiorino, L., Pandolfi, L., 2015. Evolutionary trends and stasis in carnassial teeth of European Pleistocene wolf Canis lupus (Mammalia, Canidae). Quat. Sci. Rev. 110, 36-48. https://doi.org/10.1016/j.quascirev.2014.12.009.

Savolainen, P., Zhang, Y.P., Luo, J., Lundeberg, J., Leitner, T., 2002. Genetic evidence for an East Asian origin of domestic dogs. Science 298, 1610-1613. https://doi.org/ 10.1126/science.1073906.

Schubert, B.W., Ungar, P.S., DeSantis, L.R.G., 2010. Carnassial microwear and dietary behavior in large carnivorans. J. Zool. 280 (3), 257-263. https://doi.org/10.1111/ j.1469-7998.2009.00656.x.

Schmitt, D.N., Juell, K.E., 1994. Toward the identification of coyote scatological faunal accumulations in archaeological contexts. J. Archaeol. Sci. 21 (2), 249-262. https:// doi.org/10.1006/jasc.1994.1025.

Schmidt, C.W., 2001. Dental microwear evidence for a dietary shift between two nonmaize-reliant prehistoric human populations from Indiana. Am. J. Phys. Anthropol. 114 (2), 139-145. https://doi.org/10.1002/1096-8644(200102)114:2\%3C139:: AID-AJPA1013\%3E3.0.CO, 2-9.

Schweizer, R.M., vonHoldt, B.M., Harrigan, R., Knowles, J.C., Musiani, M., Coltman, D., Novembre, L., Wayne, R.K., 2016. Genetic subdivision and candidate genes under selection in North American grey wolves. Mol. Ecol. 25 (1), 380-402. https://doi. org/10.1111/mec.13364.

Scott, R.S., Ungar, P.S., Bergstrom, T.S., Brown, C.A., Grine, F.E., Teaford, M.F., Walker, A., 2005. Dental microwear texture analysis shows within-species diet variability in fossil hominins. Nature 436 (7051), 693-695. https://doi.org/ 10.1038/nature03822.

Scott, R.S., Ungar, P.S., Bergstrom, T.S., Brown, C.A., Childs, B.E., Teaford, M.F., Walker, A., 2006. Dental microwear texture analysis: technical considerations. J. Hum. Evol. 51 (4), 339-349. https://doi.org/10.1016/j.jhevol.2006.04.006.

Selvaggio, M.M., Wilder, J., 2001. Identifying the involvement of multiple carnivore taxa with archaeological bone assemblages. J. Archaeol. Sci. 28 (5), 465-470. https:// doi.org/10.1006/jasc.2000.0557.

Shipman, P., 2015. How do you kill 86 mammoths? Taphonomic investigations of mammoth megasites. Quat. Int. 359, 38-46. https://doi.org/10.1016/j. quaint.2014.04.048.

Skoglund, P., Ersmark, E., Palkopoulou, E., Dalen, L., 2015. Ancient wolf genome reveals an early divergence of domestic dog ancestors and admixture into high-latitude breeds. Curr. Biol. 25 (11), 1515-1519. https://doi.org/10.1016/j.cub.2015.04.019.

Shannon, L.M., Boyko, R.H., Castelhano, M., Corey, E., Hayward, J.J., McLean, C., White, M.E., Said, M.A., Anita, B.A., Bondjengo, N.I., Calero, J., 2015. Genetic structure in village dogs reveals a Central Asian domestication origin. Proc. Natl. Acad. Sci. Unit. States Am. 112 (44), 13639-13644. https://doi.org/10.1073/ pnas. 1516215112.

Slater, G.J., Dumont, E.R., Van Valkenburgh, B., 2009. Implications of predatory specialization for cranial form and function in canids. J. Zool. 278 (3), 181-188.

Street, M., Napierala, H., Janssens, L., 2015. The late Palaeolithic dog from BonnOberkassel in context. In: Giemsch, L., Schmitz, R.W., Reinische, R.W. (Eds.), The Late Glacial Burial from Oberkassel Revisited, Ausgrabungen 72. Verlag Philippvon Zabern in Wissenschaftliche Buchgesellschaft, p. 253.

Stynder, D.D., DeSantis, L.R., Donohue, S.L., Schubert, B.W., Ungar, P.S., 2018. A dental microwear texture analysis of the early pliocene African Ursid Agriotherium africanum (Mammalia, Carnivora, Ursidae). J. Mamm. Evol. 1-11 https://doi.org/ 10.1007/s10914-018-9436-y.

Stynder, D.D., Ungar, P.S., Scott, J.R., Schubert, B.W., 2012. A dental microwear texture analysis of the Mio-Pliocene hyaenids from Langebaanweg, South Africa. Acta Palaeontol. Pol. 57 (3), 485-497.

Tanis, B.P., Desantis, L.R., Terry, R.C., 2018. Dental microwear textures across cheek teeth in canids: implications for dietary studies of extant and extinct canids. Palaeogeogr. Palaeoclimatol. Palaeoecol. 508, 129-138. https://doi.org/10.1016/j. palaeo.2018.07.028.

Tchernov, E., Horwitz, L.K., 1991. Body size diminution under domestication: unconscious selection in primeval domesticates. J. Anthropol. Archaeol. 10 (1), 54-75. https://doi.org/10.1016/0278-4165(91)90021-O.

Thalmann, O., Shapiro, B., Cui, P., Schuenemann, V.J., Sawyer, S.K., Greenfield, D.L., Germonpre, M.B., Sablin, M.V., LopezGiraldez, F., Domingo-Roura, X., Napierala, H., 2013. Complete mitochondrial genomes of ancient canids suggest a European origin 
of domestic dogs. Science 342 (6160), 871-874. https://doi.org/10.1126/ science. 1243650

Thalmann, O., Perri, A.R., 2018. Paleogenomic inferences of dog domestication. In: Lindqvist, C., Rajora, O.P. (Eds.). Paleogenomics, pp. 273-306. https://doi.org/ $10.1007 / 13836201827$.

Tseng, Z.J., 2012. Connecting Hunter-Schreger Band microstructure to enamel microwear features: new insights from durophagous carnivores. Acta Palaeontol. Pol. 57, 473-485. https://doi.org/10.4202/app.2011.0027.

Ungar, P.S., Brown, C.A., Bergstrom, T.S., Walker, A., 2003. Quantification of dental microwear by tandem scanning confocal microscopy and scale-sensitive fractal analyses. Scanning: J. Scan. Micros. 25 (4), 185-193. https://doi.org/10.1002/ sca.4950250405.

Ungar, P.S., 2009. Tooth form and function: insights into adaptation through the analysis of dental microwear. Front. Oral. Biol. 13, 38-43. https://doi.org/10.1159/ 000242388.

Ungar, P.S., Merceron, G., Scott, R.S., 2007. Dental microwear texture analysis of varswater bovids and early pliocene paleoenvironments of langebaanweg, western Cape province, South Africa. J. Mamm. Evol. 14 (3), 163-181. https://doi.org/ 10.1007/s10914-007-9050-x.

Ungar, P.S., Scott, J.R., Schubert, B.W., Stynder, D.D., 2010. Carnivoran dental microwear textures: comparability of carnassial facets and functional differentiation of postcanine teeth. Mammalia 74, 219-224. https://doi.org/10.1515/ mamm.2010.015.

Ungar, P.S., Abella, E.F., Burgman, J.H., Lazagabaster, I.A., Scott, J.R., Delezene, L.K., Manthi, F.K., Plavcan, J.M., Ward, C.V., 2017. Dental microwear and Pliocene paleocommunity ecology of bovids, primates, rodents, and suids at Kanapoi. J. Hum. Evol. 132, 80-100. https://doi.org/10.1016/j.jhevol.2017.03.005.

Vanak, A.T., Gompper, M.E., 2009. Dogs, Canis familiaris, as carnivores: their role and function in intraguild competition. Mamm Rev. 39 (4), 265-283. https://doi.org/ 10.1111/j.1365-2907.2009.00148.x.

Van Valkenburgh, B., Teaford, M.F., Walker, A., 1990. Molar microwear and diet in large carnivores: inferences concerning diet in the sabretooth cat, Smilodon fatalis. J. Zool. 222 (2), 319-340. https://doi.org/10.1111/j.1469-7998.1990.tb05680.x.

Van Valkenburgh, B., 1989. Carnivore dental adaptations and diet: a study of trophic diversity within guilds. In: Gittleman, J.L. (Ed.), Carnivore Behavior, Ecology, and Evolution. Cornell University Press, Ithaca, New York, pp. 410-436.

Van Valkenburgh, B., 1996. Feeding behavior in free-ranging, large African carnivores. J. Mammal. 77 (1), 240-254. https://doi.org/10.2307/1382725.

Van Valkenburgh, B., Hertel, F., 1993. Tough times at La Brea: tooth breakage in large carnivores of the late Pleistocene. Science 261 (5120), 456-459. https://doi.org/ 10.1126/science.261.5120.456.
Van Valkenburgh, B., Peterson, R.O., Smith, D.W., Stahler, D.R., Vucetich, J.A., 2019. Tooth Fracture Frequency in Gray Wolves Reflects Prey Availability. bioRxiv 658468. https://doi.org/10.1101/658468.

Velemínska, J., Brůzek, J., 2008. Early Modern Humans from Predmostí, Near Prerov, Czech Republic: A New Reading of Old Documentation. Academia, Praha.

Vila, C., Savolainen, P., Maldonado, I.R., Amorim, J.E., Rice, R.L., Honeycutt, K.A., Crandall, J.A., Lundeberg, J., Wayne, R.K., 1997. Multiple and ancient origins of the domestic dog. Science 276, 1687-1689. https://doi.org/10.1126/ science.276.5319.1687.

vonHoldt, M.B., Gray, M.M., Wayne, R.K., 2012. Genome-wide approaches for the study of dog domestication. In: Harland, J.R., Gepts, P., Famula, T.R., Bettinger, R.L., Brush, S.B., Damania, A.B., McGuire, P.E., Qualset, C.O. (Eds.), Biodiversity in Agriculture: Domestication, Evolution, and Sustainability. Cambridge University Press, pp. 275-298.

vonHoldt, B.M., Driscoll, C.A., 2016. Origins of the dog: genetic insights into dog domestication. In: Serpell, J. (Ed.), The Domestic Dog: its Evolution, Behaviour and Interactions with People. Cambridge University Press, pp. 22-41.

Wang, G.D., Zhai, W., Yang, H.C., Wang, L., Zhong, L., Liu, Y.H., Fan, R.X., Yin, T.T., Zhu, C.L., Poyarkov, A.D., Irwin, D.M., 2016. Out of southern East Asia: the natural history of domestic dogs across the world. Cell Res. 26 (1), 21. https://doi.org/ 10.1038/cr.2015.147.

Wayne, R.K., 1986. Cranial morphology of domestic and wild canids: the influence of development on morphological change. J. Morphol. 187, 301-319. https://doi.org/ 10.1111/j.1558-5646.1986.tb00467.x.

Wilson, P.J., Grewal, S., Lawford, I.D., Heal, J.N., Granacki, A.G., Pennock, D., Theberge, J.B., Theberge, M.T., Voigt, D.R., Waddell, W., Chambers, R.E., 2000. DNA profiles of the eastern Canadian wolf and the red wolf provide evidence for a common evolutionary history independent of the gray wolf. Can. J. Zool. 78 (12), 2156-2166. https://doi.org/10.1139/z00-158.

Wroe, S., McHenry, C., Thomason, J., 2005. Bite club: comparative bite force in big biting mammals and the prediction of predatory behaviour in fossil taxa. Proc. R. Soc. B: Biol. Sci. 272 (1563), 619-625. https://doi.org/10.1098/rspb.2004.2986.

Yravedra, J., Andres, M., Domínguez-Rodrigo, M., 2014. A taphonomic study of the African wild dog (Lycaon pictus). Arch. Anthrop. Sci. 6 (2), 113-124. https://doi.org/ 10.1007/s12520-013-0164-1.

Zeder, M.A., Hesse, B., 2000. The initial domestication of goats (Capra hircus) in the Zagros Mountains 10,000 years ago. Science 287 (5461), 2254-2257. https://doi. org/10.1126/science.287.5461.2254.

Zeder, M.A., 2012. The domestication of animals. J. Anthropol. Res. 68 (2), 161-190. https://doi.org/10.3998/jar.0521004.0068.201. 